HUMANIKA Vol. 23 No.1 (2016) ISSN 1412-9418

Civic Culture Dalam Nilai-Nilai Budaya Dan Kearifan Lokal Masyarakat Bali Aga Desa Trunyan

I Wayan Trisna Mahardika, Cecep Darmawan

\title{
CIVIC CULTURE DALAM NILAI-NILAI BUDAYA DAN KEARIFAN LOKAL MASYARAKAT BALI AGA DESA TRUNYAN
}

\author{
Oleh : \\ I Wayan Trisna Mahardika, dan Cecep Darmawan \\ E-Mail : wayantrisna69@gmail.com \\ Program Magister Pendidikan Kewarganegaraan, Sekolah Pascasarjana, Universitas \\ Pendidikan Indonesia \\ J1. Dr Setiabudi No. 229, Bandung, Jawa Barat, Indonesia
}

\begin{abstract}
This research aims to see the civic culture on the culture and local wisdom of Bali Aga people in Trunyan, as well as to find how to preserve that. The method which used is qualitative with ethnography approach. The result shows that there is civic culture in the culture and local wisdom of Bali Aga people. That is found on culture of Ngayah, Paruman, Mepasah, and Barong Brutuk also in the value of local wisdom called Menyama Braya. The result also shows the preservation is run naturally along with belief in their ancestors and the bond between people and tradition.
\end{abstract}

Keywords : Civic Culture, Culture, Local Wisdom, Bali Aga.

\section{PENDAHULUAN}

\subsection{Latar Belakang}

Trunyan sebagai desa Bali Aga, memiliki berbagai budaya dan kearifan lokal yang unik, inilah yang membuat perbedaaan desa Bali Aga khususnya desa Trunyan dengan desa-desa lain yang ada di Bali. Dalam hubungannya dengan menjaga, memajukan, dan melestarikan kebudayaan daerah, telah diatur dalam Undang-Undang Dasar Negara Republik Indonesia Tahun 1945 pada pasal 32 ayat 1 dan 2 yaitu: 1) Negara memajukan kebudayaan nasional Indonesia ditengah peradaban dunia dengan menjamin kebebasan masyarakat dalam memelihara dan mengembangkan budayanya. 2) Negara menghormati dan memelihara bahasa daerah sebagai kekayaan budaya nasional. Jelaslah bahwa negara Indonesia menjamin dan mendukung keberadaan budaya daerah yang menjadi bagian dari budaya nasional. Budaya atau kearifan lokal merupakan cerimnan dari kepribadian bangsa yang memang patut dilestarikan guna menangkal pengaruhpengaruh negatif dari luar.

Pengembangan dan pelestarian nilainilai budaya serta kearifan lokal, dapat mengarah pada salah satu bidang ilmu yang mengkaji kearifan lokal atau budaya daerah yang terdapat didalam warganegara, yaitu civic culture atau budaya kewarganegaraan. Menurut Winataputra (2012:57) civic culture merupakan "budaya yang menopang kewarganegaraan yang berisikan seperangkat ide-ide yang dapat diwujudkan secara efektif dalam representasi kebudayaan untuk tujuan pembentukan identitas warganegara". Kearifan lokal yang tumbuh dan berkembang dalam masyarakat Bali Aga di desa Trunyan merupakan bagian dari jati diri bangsa, karakter dan budaya nasional.

Sebagai bagian dari masyarakat Indonesia khususnya Bali, peneliti merasakan kerisauan yang amat mendalam 
kemana arah yang akan dituju oleh perubahan sosial budaya masyarakat Indonesia, khususnya masyarakat Bali Aga di desa Trunyan. Hal ini mengingat pola kehidupan masyarakat di Bali pada umunya yang telah beralih pada perilaku hedonis dan liberal. Pergaulan generasi muda yang kian memperihatinkan menjadi salah satu kekhawatiran yang ditakutkan dapat mengubah atau menggerus nilai-nilai kebaikan yang telah tumbuh dan berkembang dalam masyarakat Trunyan.

Derasnya arus globalisasi yang diperparah dengan pariwisata yang tidak terkendali adalah masalah utama yang pelan namun pasti dapat mendegradasi nilai-nilai budaya dan kearifan lokal yang ada pada masyarakat Bali Aga di desa Trunyan. Desa Trunyan yang sudah menjadi bagian dari eksploitasi pariwisata di Bali, mestinya mendapat perhatian khusus baik dari pemerintah, ahli, maupun masyarakat. Karena sebagai desa dengan warisan sejarah dan budaya yang merupakan warisan leluhur, sudah menjadi kewajiban bersama dalam menjaganya. Yang peneliti takutkan adalah tidak disadarinya dampak negatif dari pertemuan budaya yang dibawa wisatawan mancanegara. Tanpa kemampuan untuk memilah mana yang baik dan buruk, tentu akan dapat menggerus budaya lokal itu sendiri.

Masih rendahnya pemahaman, komitmen, dan kesadaran tentang pentingnya pelestarian kearifan lokal pada masyarakat Bali Aga desa Trunyan juga dapat membawa budaya dan kearifan lokal pada kepunahan. Hal ini tidak hanya berlaku bagi masyarakat setempat, tapi juga bagi pemerintah dan masyarakat Bali pada umunya. Kesadaran akan pentingnya nilai-nilai kearifan lokal maupun budaya sebagai kekayaan budaya Nasional mestinya dapat memberikan manfaat baik bagi keberadaan kearifan lokal atau budaya yang dimaksudkan. Penelitian ini bermaksud untuk menggali budaya kewarganegaraan yang ada dalam budaya dan kearifan lokal masyarakat Bali Aga di desa Trunyan, dengan harapan nantinya dapat dijadikan acuan atau tambahan pengetahuan untuk memahami pentingnya nilai-nilai budaya dan kearifan lokal dalam mewujudkan karakter bangsa yang baik.

\subsection{Rumusan Masalah dan Tujuan Penelitian}

Berdasarkan penjabaran latar belakang penelitian di atas, maka fokus yang menjadi rumusan masalah secara umum yaitu : "Bagaimana Civic Culture yang Terkandung dalam Nilai-Nilai Budaya dan Kearifan Lokal Masyarakat Bali Aga Desa Trunyan?". Agar penelitian ini lebih terfokus pada pokok permaslahan, maka masalah umum tersebut dijabarkan dalam sub-sub masalah yang sekaligus menjadi pertanyaan penelitian yaitu sebagi berikut :

1. Bagaimana deskripsi kebudayaan dan kearifan lokal masyarakat Bali Aga Desa Trunyan?

2. Bagaimana civic culture yang terkandung dalam nilai-nilai budaya dan kearifan lokal masyarakat Bali Aga desa Trunyan?

3. Bagaimana kendala dan upaya dalam melestarikan nilai-nilai kearifan lokal masyarakat Bali Aga desa Trunyan?

Berdasarkan rumusan masalah tersebut, maka tujuan umum dari penelitian ini adalah untuk mengidentifikasi : "Civic Culture dalam Nilai-Nilai Budaya dan Kearifan Lokal Masyarakat Bali Aga di Desa Trunyan". Berdasarkan rumusan masalah juga penelitian ini diarahkan untuk mencapai beberapa tujuan khusus sebagai berikut :

1. Mendeskripsikan kebudayaan dan kearifan lokal masyarakat Bali Aga Desa Trunyan

2. Mengidentifikasi civic culture yang terkandung dalam nilai-nilai budaya dan kearifan lokal masyarakat Bali Aga desa Trunyan, serta 
HUMANIKA Vol. 23 No.1 (2016) ISSN 1412-9418

Civic Culture Dalam Nilai-Nilai Budaya Dan Kearifan Lokal Masyarakat Bali Aga Desa Trunyan

I Wayan Trisna Mahardika, Cecep Darmawan

3. Mengidentifikasi kendala dan upaya dalam melestarikan nilainilai kearifan lokal masyarakat Bali Aga desa Trunyan.

\subsection{Metode Penelitian}

Peneliti menggunakan pendekatan kualitatif dengan etografi sebagai metode penelitian. Hal ini disebabkan karena kualitatif dapat menggali lebih dalam mengenai permasalahan manusia sebagai instrumen penelitian. Metode wawancara, observasi dan dokumentasi, juga teknik teknik analisisnya, merupakan ekstensi dari prilaku manusia, seperti mendengarkan , melihat, bicara, berinteraksi dan bertanya. Penelitian kualitatif adalah penelitian yang berguna untuk memperoleh penemuan penemuan yang tidak terduga sebelumnya dan membangun kerangka teoritis baru. Dengan demikian, pendekatan kualitatif merupakan pendekatan naturalistik karena situasi di lapangan yang apa adanya dan tidak dimanipulasi. Sugiyono (2009:15) menjelaslkan bahwa Metode penelitian kualitatif adalah metode yang berlandaskan pada filsafat postpositivisme, digunakan untuk meneliti pada kondisi obyek yang alamiah, (sebagai lawan eksperimen) dimana penelitian adalah sebagai instrumen kunci, pengembalian sampel sumber data dilakukan secara purposive dan snowball.

Dalam penelitian ini, peneliti berharap dapat memperoleh informasi dan data yang akurat dalam proses penelitian. Alasan lain mengapa peneliti memilih pendekatan kualitatif adalah karena data yang akan diperoleh dari proses penelitian ini nantinya lebih banyak menyangkut perbuatan dan ungkapan kata-kata dari responden yang sebisa mungkin bersifat alamiah tanpa adanya rekayasa atau manilpulasi serta pengaruh dari luar guna mendapatkan kebenaran ilmiah yang alamiah. Sebagaimana dijelaskan oleh Muchtar,S.A. (2015:5) bahwa kebenaran ilmiah yang alamiah diperoleh melalui kegiatan penelitian yang menggunakan prosedur penelitian kualitatif melalui penafsiran mendalam terhadap fenomena alamiah.

Sedangkan etnografi dapat membahas tentang suku bangsa atau suatu masyarakat, yaitu mengenai kebudayaan lokal suku atau masyarakat tersebut. Etnografi akan menggali lebih jauh makna dari setiap budaya dan kearifan lokal yang ada di desa Trunyan. Etnografi juga dapat mendeskripsikan secara detail teori-teori penduduk asli yang telah diuji dalam situasi kehidupan aktual selama beberapa generasi. Spradley (2006:18) menjelaskan bahwa etnografi dapat menunjukkan berbagai peristiwa budaya dan bagaimana orang dengan perspektif berbeda berinteraksi. Maka akan sangat tepat jika penelitian ini diarahkan dengan metode etnografi mengingat fokus kajian dari penelitian ini adalah budaya dan kearifan lokal di desa Trunyan sebagai salah satu desa Bali Aga.

Penelitian ini diarahkan untuk menggali atau mendeskripsikan kearifan lokal yang ada di Desa Trunyan, jadi metode yang paling cocok adalah metode penelitian etnografi. Creswell (2010:294) menjelaskan tujuan penelitian etnografi adalah memperoleh gambaran umum mengenai subjek penelitian. Penelitian ini menekankan aspek pemotretan pengalaman individu-individu sehari-hari dengan cara mengobservasi dan mewawancarai mereka. Penelitian ini melibatkan wawancara mendalam dan observasi secara terus menerus pada partisipan dalam situasi tertentu.

Demikian juga halnya dengan Muchtar, S.A. (2015:102) yang menjelaskan bawha inti etnografi ialah mencoba memahami makna perbuatan dan kejadian bagi orang yang bersangkutan menurut kebudayaan dan pandangan mereka. Kebudayaan antara lain kelakuan, artifak atau benda-benda yang dibuat, hanya berupa semacam permukaan telaga 
yang dalam dan mengandung aspek dan pengetahuan kultural yang luas. Ditegaskan lagi bahwa pengetahuan ini, yang biasanya tersembunyi bagi orang luar, sangat fundamental untuk menginterpretasikan kelakuan dari seseorang.

Dari pemaparan diatas, dapat disimpulkan bahwa dalam penelitian etnografi, peneliti berusaha untuk mempelajari suatu kelompok budaya selama periode waktu tertentu dengan mengumpulkan data melalui observasi. Proses penelitian bisa fleksibel dan berkembang secara kontekstual sesuai dengan realita yang ditemui di lapangan. Etnografi adalah uraian dan penafsiran suatu budaya atau sistem kelompok sosial. peneliti menguji kelompok tersebut dan mempelajari pola perilaku, kebiasaan, dan cara hidup. Etnografi adalah sebuah proses dan hasil dari sebuah penelitian. Sebagai proses, etnografi melibatkan pengamatan yang cukup panjang terhadap suatu kelompok, dimana dalam pengamatan tersebut peneliti terlibat dalam keseharian hidup responden atau melalui wawancara satu persatu dengan anggota kelompok tersebut. Peneliti mempelajari arti atau makna dari setiap perilaku, bahasa, dan interaksi dalam kelompok. Penelitian etnografi dalam hal ini berfungsi untuk mengkonsepsi nilai-nilai budaya dan kearifan lokal masyarakat Bali Aga di desa Trunyan sebagai pusat pembudayaan, mengkaji dan menyajikan pengalaman terbaik tentang interaksi, relasi dan situasi sosial budaya, praktek sosial budaya, organisasi adat, serta nilai-nilai di masyarakat yang menjadi bagian dari civic culture yang terdapat dalam kehidupan masyarakat Bali Aga di desa Trunyan.

\subsection{Kerangka teori}

Civic culture sangat erat kaitannya dengan identitas bangsa. Identitas bangsa dalam hal ini dimaksudkan sebagai identitas yang terkait budaya, kearifan lokal, serta adat istiadat yang ada di tiaptiap daerah di Indonesia. Pengetahuan tentang civic culture akan sangat berguna ditengah heterogenitas masyarakat Indonisa sebagai pedoman kehidupan bersama. Menurut Winataputra (2012:57) civic culture merupakan "budaya yang menopang kewarganegaraan yang berisikan seperangkat ide-ide yang dapat diwujudkan secara efektif dalam representasi kebudayaan untuk tujuan pembentukan identitas warganegara".

Aspek sosial-kultural dalam bangsa ini telah mewujudkan integritas bangsa yang beragam dan bermacam-macam, diantaranya terdiri dari budaya-budaya dan etnisitas nasional. Dengan demikian hal itu dapat berubah menjadi budaya yang dapat merekatkan perbedaan sebagai salah satu alternatif untuk membangun aspek pendidikan, perekonomian, dan kesejahteraan masyarakat, untuk mewujudkan persatuan bangsa Indonesia. Aspek sosial-kultural yang beranekaragam itu perlu didasari dan diwarnai dengan nilai-nilai yang terkandung dalam ideologi negara Indonesia yakni Pancasila, agar dapat diupayakan menjadi budaya nasional. Konsep inilah yang lebih dikenal sebagai budaya kewarganegaraan atau civic culture. Winataputra dan Budimansyah (2012:233) mengemukakan bahwa Civic Culture .. a set of ideas that can be embodied effectively in cultural representation for the perpose of shaping civic identities atau seperangkat ide-ide yang dapat diwujudkan secara efektif dalam representasi kebudayaan untuk membentuk identitas warga negara.

Civic culture berada dalam domain sosial kultural yang berorientasi pada pembentukan kualitas personal-individual warga negara. Civic culture bersifat psikososial yang perangkat gagasan atau set of ideas. Civic culture berkenaan dengan proses adaptasi psikososial individu dari kaitan budaya komuniter (keluarga, suku, masyarakat lokal) dalam sebuah ikatan kewarganegaraan. Maka dari 
itu, adalah sebuah anugerah jika sebuah bangsa memiliki kekayaan budaya yang beragam adanya seperti Indonesia. Suku bangsa yang memiliki karakteristiknya masing-masing akan memiliki karakternya sendiri yang dibingkai dalam harmoni kebhinekaan. Civic culture dalam konteks bangsa Indonesia, menggambarkan karakter warga negara Indonesia seperti layaknya yang tertuang dalam nilai-nilai Pancasila.

Secara umum Effendi dan Sapriya (2004:76) menegaskan sifat dan perilaku warga negara yang baik dan bertanggung jawab ditandai oleh beberapa ciri, yakni:

a. Menyadari akan kedudukannya sebagai warga negara.

b. Memahami aturan atau hukum yang berlaku terhadap dirinya di setiap lingkungan kehidupan.

c. Memahami dan menyadari kewajiban dan hak-haknya sebagai warga negara.

d. Melaksanakan kewajibannya sebagai warga negara dengan penuh keikhlasan dan rasa tanggung jawab.

e. Menghindari sikap dan perilaku yang menimbulkan konflik antar sesama.

f. Menumbuhkan sikap mau bekerjasama dengan sesama warga negara untuk membangun kehidupan berbangsa dan bernegara.

Sifat dan perilaku warga negara yang baik dan bertanggung jawab memberikan manfaat bagi kehidupan bermasyarakat, berbangsa, dan bernegara. Sebaliknya, sifat dan perilaku warga negara yang buruk dan tidak bertanggung jawab dapat menimbulkan kerugian bagi kehidupan bermasyarakat, berbangsa, dan bernegara. Beberapa manfaat dari sifat dan perilaku warga negara yang baik dan bertanggung jawab dalam kehidupan bermasyarakat, berbangsa, dan bernegara diantaranya (Effendi dan Sapriya, 2004:76):
a. Menciptakan keamanan dan kedamaian hidup.
b. Memperlancar pembangunan nasional.
proses
c. Memupuk rasa persatuan dan kesatuan bangsa.
d. Menciptakan ketertiban hidup dalam masyarakat.
e. Menciptakan ketenangan dan kebahagiaan hidup dalam bermasyarakat.

Dengan mengacu pada penjelasan di atas, dapat disimpulkan bahwa yang menjadi ciri atau karakteristik budaya kewarganegaraan (civic culture) dalam konteks bangsa Indonesia yaitu: nilai-nilai dalam warga negara, sikap dan perilaku warga negara yang mencerminkan Pancasila, civic virtue atau akhal kewarganegaraan, adanya budaya yang menopang kewarganegaraan (berisikan seperangkat ide-ide yang dapat diwujudkan secara efektif dalam representasi kewarganegaraan untuk tujuan pembentukan identias warga negara), serta berkenaan dengan proses adaptasi psikososial individu dari budaya komuniter.

Keberadaan identitas suatu bangsa tidak terlepas dari kebudayaan daerahnya masing-masing. Dimana budaya merupakan salah satu unsur penting dalam identitas suatu bangsa. Identitas bangsa Indonesia yang merupakan salah satu negara kepulauan tentu mengakui perbedaan tiap daerah yang berupa budaya, bahasa, adat, kesenian dan lain sebagainya sebagai unsur pembentuk identitas nasional. Kebudayaan yang berasal dari setiap daerah secara utuh menjadi bagian dari budaya nasional yang turut membentuk kepribadian warga negara. Dalam hal ini fungsi kebudayaan adalah sebagai pembentuk karakter masyarakat. Dengan banyaknya daerah yang ada di Indonesia, tentu menjadikan negara ini sangat kaya akan budaya dan masyarakat daaerahnya yang dirangkul menjadi satu dalam bingkai Bhineka Tunggal Ika. Suku 
bangsa seperti yang dijelaskan oleh Koentjaraningrat (2009:215) merupakan “...suatu golongan manusia yang terikat oleh kesadaran dan identitas akan kesatuan kebudayaan". Hal ini berarti masyarakat yang digolongkan dalam kesatuan atau suatu suku bangsa tertu, memiliki kesamaan atau kesatuan dalam hal budya. Suku bangsa sangat terikat oleh kesamaan budaya, bahasa, dan adat istiadat yang merupakan bagian dari masyarakat itu sendiri.

Kearifan lokal adalah sistem nilainilai yang berisikan pengetahuan, gagasan, kepercayaan yang menjadi nilai utama dalam suatu masyarakat tertentu. Kearifan lokal dikenal jiga dengan istilah local wisdom yang jika merujuk pada pada pengertian kearifan lokal secara etimologi terdiri dari dua kata, dimana kearifan berarti kebijaksanaan (wisdom) dan lokal (local) memiliki arti setempat. Dengan demikian dapat dipahami bahwa kearifan lokal merupakan suatu usaha manusia dengan menggunakan akal budinya (kognisi) untuk bertindak dan bersikap terhadap sesuatu, objek, atau peristiwa yang terjadi dalam ruang tertentu (Nuraeni \& Alfan, 2013:68). Dalam disiplin ilmu antropologi, kearifan lokal dikenal dengan istilah local genius, yakni keseluruhan karakteristik budaya masyarakat dalam gagasan-gagasan, nilai-nilai, pandanganpandangan setempat yang bersifat bijaksana, penuh kearifan, bernilai baik, yang tertanam dan diikuti oleh anggota masyarakatnya.

Kearifan lokal terbentuk sebagai keunggulan budaya masyarakat setempat maupun kondisi geografis dalam arti luas. Kearifan lokal merupakan produk budaya masa lalu yang patut secara terus-menerus dijadikan pegangan hidup. Meskipun bernilai lokal tetapi nilai yang terkandung di dalamnya dianggap sangat universal (Gobyah, dalam Sartini, 2004:112). Kearifan lokal diartikan sebagai salah satu unsur kebudayaan yang unggul dalam suatu masyarakat dan menjadi ciri serta digunakan sebagai pegangan hidup. Jelaslah bahwa kearifan lokal dalam praktiknya akan mewujudkan sebuah karakter dari masyarakat dan berujung pada nilai-nilai karakter bangsa. Karena bagaimanpun, jika ditelaah lebih jauh maka nilai-nilai yang terkandung didalamnya juga memiliki makna yang lebih luas dan universal. Contohnya saja kearifan lokal Tri Hita Karana yang ada dan menjadi panutan hidup bagi masyarakat Bali. Didalamnya terakandung nilai-nilai kebaikan yang memberikan nasihat untuk selalu menjaga hubungan yang baik antara manusia dengan sesamanya, manusia dengan Tuhan, serta manusia dengan alam atau lingkungannya.

Kedudukan kearifan lokal penting dalam kehidupan bermasyarakat, berbangsa dan bernegara. Hal ini karena kearifan lokal merupakan kekuatan yang mampu bertahan terhadap unsur-unsur yang datang dari luar dan mampu berkembang pada masa-masa mendatang. Hilang atau musnahnya kearifan lokal di masyarakat berarti pula memudarnya kepribadian masyarakat. Jika kearifan lokal mampu bertahan dan berkembang, hal itu juga menunjukkan kuatnya kepribadian masyarakat tersebut. Hal demikian menjadi penting untuk mempertahankan dan mengembangkan learifan lokal pada seluruh aspek kehidupan masyarakat yang mencakup gaya hidup, pola dan sikap, persepsi masyarakat, serta orientasi nilai masyarakat.

Kearifan lokal dapat disimpulkan sebagai kepribadian, identitas kultural masyarakat yang berupa nilai, norma, etika, kepercayaan, adat-istiadat dan aturan khusus yang telah teruji kemampuannya sehingga dapat bertahan secara terusmenerus. Kearifan lokal pada prinsipnya benilai baik dan merupakan keunggulan budaya masyarakat setempat dan berkaitan dengan kondisi geografis secara luas. Oleh karena hakikat kearifan lokal yang demikian maka ia akan 
HUMANIKA Vol. 23 No.1 (2016) ISSN 1412-9418

Civic Culture Dalam Nilai-Nilai Budaya Dan Kearifan Lokal Masyarakat Bali Aga Desa Trunyan

I Wayan Trisna Mahardika, Cecep Darmawan

merefleksikan kondisi budaya Nusantara yang Bhineka Tunggal Ika. Kearifan lokal berisikan pengetahuan dimana pengetahuan-pengetahuan tersebut muncul dari proses belajar, adaptasi, pengalaman bahkan beberapa diantanya berasal dari cerita-cerita, legenda, nyanyian-nyanyian, ritual-rritual, maupun norma-norma atau hukum adat setempat yang berisikan nilainilai kearifan dan menjadi simbol atau ciri khas sebuah budaya atau masyarakat setempat. Kemudian pada akhirnya nilainilai yang dipegang masyarakat sebagai suatu kebaikan ini, dijadikan sebagai acuan untuk menjalani kehidupannya dalam berbagai aspek. Dengan kata lain, kearifan lokal adalah roh yang menjiwai budaya masyarakat tertentu. Seperti yang dijelaskan pula oleh Gobyah (Sartini, 2004:57) bahwa kearifan lokal (local wisdom) adalah "kebenaran yang telah mentradisi atau ajeg dalam suatu daerah. Kearifan lokal adalah perpaduan antara nilai-nilai budaya dengan nilai-nilai kepercayaan".

\section{HASIL DAN PEMBAHASAN \\ 2.1. Deskripsi Budaya dan Kearifan lokal Masyarakat Bali Aga desa Trunyan serta Civic Culture yang Terkandung di Dalamnya.}

Hasil penelitian menunjukkan beberapa budaya dan kearifan lokal yang dimiliki masyarakat Bali Aga di desa Trunyan serta hubungannya dengan budaya kewarganegaraan atau civic culture. Budaya yang dimaksud yaitu mepasah, paruman, ngayah, dan barong brutuk. Sedangkan kearifan lokal masyarakat Bali Aga di desa Trunyan adalah konsep menyama braya.

Mepasah merupakan upacara kematian yang amat unik. Upacara kematian di Desa Trunyan sedikit berbeda dengan daerah-daerah pada umumnya yang terdapat di Bali. Mayat diletakkan diatas tanah yang arealnya sudah dibatasi dan di areal tersebut terdapat sebuah pohon taru menyan yang seakan-akan menyegel aroma mayat agar tidak tercium. Berdasarkan wawancara, observasi dan dokumentasi yang telah dilakukan peneliti, upacara ini dipercaya memiliki makna yang sama dengan upacara ngaben pada umumnya di Bali. Tujuannya adalah untuk mengembalikan atman (roh) pada sang pencipta dan dihormati sebagai leluhur. Mepasah melalui beberapa tahapan yang melibatkan sesajen dan seluruh masyarakat desa Trunyan terutama yang laki-laki dalam proses kegiatannya.

Paruman adalah sebuah kegiatan musyawarah secara adat yang dilakukan oleh masyarakat Trunyan. Paruman merupakan bentuk musyawarah yang sangat demokratis, karena setiap warga di desa Trunyan memiliki hak suara yang sama sehingga keputusan yang di ambil dapat memuaskan diri setiap orang untuk mencapai kebahagiaan dan kesentosaan bagi seluruh masyarakat. Paruman di desa trunyan diadakan rutin setiap 15 hari sekali, tepatnya pada bulan purnama dan saat bulan mati (tilem) sesuai perhitungan kalender bali. Selain melakukan musyawarah, paruman juga dilakukan untuk pemberian sanksi pada pelanggaran aturan atau hukum adat setempat, baik itu berupa pedosaan (denda) maupun sanksi sosial yang lain dimana sanksi yang paling keras adalah dikeluarkan dari desa. Paruman inilah yang dijadikan media untuk melakukan diskusi mengenai masalah tersebut, termasuk juga membahas hal-hal seperti gotong-royong, bersihbersih desa, piodalan (upacara), dan lain sebagainya. Oleh karena dilakukan secara rutin, maka paruman juga dijadikan sebagai ajang silaturahmi bagi masyarakat desa Trunyan.

Ngayah adalah bentuk kegiatan sosial masyarakat Bali Aga di desa Trunyan yang dilakukan secara bersamasama dan sukarela tanpa mengharapkan imbalan atau bayaran. Terdapat sejumlah kewajiban yang harus dipenuhi atau dijalani oleh masyarakat sebagai salah satu wujud tanggung jawab sosial. Kewajiban- 
kewajiban ini dapat dibedakan menjadi tiga, yaitu kewajiban religius terutama Pura tempat persembahyangan (pengayah pura), kewajiban yang berkaitan dengan kegiatan sosiokultural banjar adat (pengayah banjar adat) dan kewajiban berupa dedikasi dan loyalitas pada adat dan desa. Bekerja menurut pandangan masyarakat Trunyan adalah bekerja yang sesuai dengan kewajibann dan dharma atau kebaikan, bekerja yang tidak hanya berfokus pada hasil yang diharapkan.

Barong Brutuk adalah sebuah tarian sakral yang masih ajeg hingga saat ini di desa Trunyan. Tarian ini biasa ditarikan ketika hari odalan atau upacara di Pura Ratu Pancering Jagat. Tarian ini ditarikan oleh penari pria yang diambil dari anggota pemuda atau biasa disebut sekaa teruna. Sebelum diselenggarakannya tarian sakral itu, para taruna harus melewati proses sakral atau penyucian diri selama 42 hari. Barong Brutuk, adalah tarian Barong yang sangat kuno dan hanya ada di Desa Trunyan yang sejak ratusan tahun lalu dihuni oleh warga Bali Aga. Tarian ini menggambarkan kehidupan para leluhur masyarakat setempat. Barong Brutuk ini adalah unen-unen (anak buah) dari leluhur orang Trunyan, yakni Ratu Sakti Pancering Jagat dengan istrinya Ratu Ayu Dalem Pingit Dasar. Terdapat nilai-nilai yang menjadi bagian bangsa Indonesia meliputi nilai ke-Tuhanan, kepercayaan, tanggung jawab, gotong royong, serta kebersamaan yang terjalin antar penduduk desa Trunyan. Dalam budaya Barong Brutuk, masyarakat desa Trunyan saling bahu membahu dalam menjalankannya. Diperlukan kesabaran dan tanggungjawab yang amat tinggi utamanya bagi taruna atau pemuda yang terpilih untuk memerankan Barong Brutuk.

Menyama braya memiliki makna plural, yakni menghargai perbedaan dan menempatkan orang lain sebagai keluarga. Menyama braya bagi masyarakat Trunyan selain sebagai kearifan lokal yang menjadi landasan moral dalam membangun relasi sosial, juga merupakan kekayaan utama dalam hidup dan sebagai jalan untuk menggapai kedamaian dan keharmonisan. Dengan berpikir positif akan terwujud tindakan harmonis, apabila tiap jiwa mampu berpikir positif maka akan ditemukan kehidupan yang harmoni, sesuai dengan aturan nilai-nilai etika dan moral. Hal ini tentu tidak akan berjalan dengan baik tanpa adanya kesadaran yang luar biasa dari masyarkat itu sendiri. Dan jika dihubungkan dengan civic culture atau budaya kewarganegaraan sudah barang tentu masyarakat Bali Aga desa Trunyan telah menunjukkan sikap saling menghormati, kekeluargaan, dan cinta damai.

Jika dikaitkan dengan nilai-nilai fundamental yang terkandung dalam dasar negara, maka budaya dan kearifan lokal masyarakat Bali Aga desa Trunyan, mengandung nilai-nilai kepercayaan seperti yang ada dalam Pancasila yaitu nilai-nilai ketuhanan, kemanusiaan, persatuan, kerakyatan dan keadilan sosial. Sama halnya dengan yang terjadi di desa Trunyan, masyarakat menerapkan kebudayaannya dalam kehidupan seharihari yang secara tidak langsung berarti telah menerapkan nilai-nilai Pancasila ke dalam kehidupan sehari-sehari melalui kebudayaan.

Hal ini sesuai dengan teori fungsional dari Mallinowski dalam (Koentjaraningrat, 2009, hlm:171) yang menjelaskan bahwa segala aktivitas kebudayaan itu sebenarnya bermaksud memuaskan suatu rangkaian dari sejumlah kebutuhan naluri manusia yang berhubungan dengan seluruh kehidupannya. Berdasarkan teori ini budaya masyarakat Bali Aga di desa Trunyan melalui setiap budaya yang meliputi Mepasah, Ngayah, Paruman dan Barong Brutuk dapat berfungsi dalam kehidupan masyarakat yang menyangkut tuntutan hidup bagi masyarakat Bali Aga di desa Trunyan. 
HUMANIKA Vol. 23 No.1 (2016) ISSN 1412-9418

Civic Culture Dalam Nilai-Nilai Budaya Dan Kearifan Lokal Masyarakat Bali Aga Desa Trunyan

I Wayan Trisna Mahardika, Cecep Darmawan

Mangacu pada teori Winataputra (2012:57) yang menjelaskan civic culture sebagai "budaya yang menopang kewarganegaraan yang berisikan seperangkat ide-ide yang dapat diwujudkan secara efektif dalam representasi kebudayaan untuk tujuan pembentukan identitas warga negara". Dalam konteks civic culture, kebudayaan masyarakat Bali Aga di desa Trunyan memiliki nilai-nilai yang ditandai dengan adanya sikap warga negara berupa : nilai religius atau keTuhanan, tanggung jawab, saling menghormati, persaudaraan, kepedulian sosial, musyawarah atau demokrasi, gotong royong, partisipasi, solidaritas dan peduli lingkungan. Senada dengan pendapat Winataputra (2012:62) bahwa unsur dari budaya kewarganegaraan (civic culture) adalah civic virtue atau kebajikan atau akhlak kewarganegaraan yang mencakup keterlibatan aktif warga negara, hubungan kesejajaran/egaliter, saling percaya dan toleran, kehidupan yang kooperatif, dan semangat kemasyarakatan.

Melalui budaya dan kearifan lokal, masyarakat Bali Aga desa Trunyan dapat menjadi warga negara yang lebih baik dan mencerminkan nilai-nilai civic culture, serta memiliki keyakinan dan pemahaman yang baik mengenai budaya lokalnya dan mewujudkan warga negara yang cerdas dan baik (smart and good citizen). Menjadikan budaya lokal sebagai sarana pengembangan pedoman etik terutama bagi masyarakat Bali dan bangsa Indonesia pada umumnya karena mengandung nilainilai Pancasila yang menjadi faktor penting dalam pengembangan budaya kewarganegaraan atau civic culture.

\subsection{Pelestarian Budaya dan Kearifan Lokal Masyarakat Bali Aga Desa Trunyan}

Memahami budaya dan menjadikan budaya sebagai warna keseharian merupakan tanggung jawab para pengusung budaya itu sendiri. Seperti budaya Bali Aga yang terdapat di desa
Trunyan, maka yang bertanggungjawab melestarikannya adalah orang Bali Aga desa Trunyan sendiri. Pelaksanaan upacara-upacara adat merupakan kewajiban bagi masyarakat Trunyan yang secara tidak langsung mereka telah ikut andil dalam pelestarian kebudayaannya sendiri. Sistem kepercayaan yang tertanam sejak dahulu menjadikan upacara-upacara tersebut sebagai sebuah kewajiban dan keharusan. Apabila tidak dilaksanakan maka masyarakat meyakini hal tersebut dapat menimbulkan kageringan (malapetaka) bagi yang tidak menjalankannya.

Masyarakat desa Trunyan telah melakukan upayanya dalam proses pelestarian kebudayaan dan kearifan lokal yang mereka miliki. Pelestarian dilakukan dengan cara melakukan setiap upacaraupacara adat, pemebrian sanksi bagi pelanggaran, penanaman sejak dini pada generasi muda, truna truni atau muda mudi yang ikut secara langsung dalam kegiatan adat, mewariskan kearifan lokal dan budaya pada anak-anak, membentengi diri dari wisatawan yang datang serta peran pemerintah yang juga tidak kalah penting. Bantuan pemerintah dalam hal ini sangat berguna bagi keberlangsungan budaya dan kearifan lokal masyarakat Bali Aga di desa Trunyan. Penyuluhan akan pentingnya kebudayaan dan kearifan lokal sebagai identitas dan jati diri masyarakat desa Trunyan akan berpengaruh pada upaya mereka dalam pelestariannya. Masyarakat trunyan sebenarnya sudah sangat dijiwai oleh kebudayaan dan kearifan lokal yang mereka miliki. Hal ini dibuktikan oleh kuatnya adat dan karakter orang Bali Aga di desa Trunyan.

Dalam jurnal yang dikarang oleh Christeward Alus (2014), dijelaskan tentang pelestarian budaya yang menuntut peran aktif dari lembaga dan pemangku desa yang harus bekerjasama dengan dengan masyarakat dalam mempertahankan nilai-nilai budaya dan kearifan lokal. Berarti akan perlu adanya 
kreatifitas masyarakat, dan akan lebih baik apabila ada singkronisasi program antara lembaga adat dengan pemerintah daerah dalam kegiatan upaya pelestarian budaya dan kearifan lokal. Begitu pula dengan apa yang seharusnya dilakukan masyarakat Bali Aga di desa Trunyan. Masyarakat, pemuda, lembaga desa dan pemerintah harus lebih aktif dalam memberikan fasilitas pelestarian budaya dan kearifan lokal.

Sartini (2004:118) menambahkan bahwa ada banyak peluang untuk pengembangan wacana kearifan lokal Nusantara. Di samping itu kearifan lokal dapat didekati dari nilai-nilai yang berkembang di dalamnya seperti nilai religius, nilai etis, estetis, intelektual atau bahkan nilai lain seperti ekonomi, teknologi dan lainnya. Maka kekayaan kearifan lokal menjadi lahan yang cukup subur untuk digali, diwacanakan dan dianalisis mengingat faktor perkembangan budaya terjadi dengan begitu pesatnya. Jika dihubungkan dengan kearifan lokal yang ada di desa Trunyan maka akan sangat penting adanya untuk menggali, mewacanakan, serta menganalisis kearifan lokal masyarakat Bali Aga utamanya yang menyangkut dharma, tat twam asi dan konsep menyama braya yang menjadi bagian dari kearifan lokal masyarakat Bali Aga di desa Trunyan.

Pelestarian budaya dan kearifan lokal menuntut peran generasi muda yang aktif. Akan tetapi yang peneliti dapatkan bahwa generasi muda di desa Trunyan masih kurang kreatif dalam hal ini. Jika di desa lain muda mudi biasa melakukan kegiatan sperti pasraman, kegiatan ini tidak peneliti temukan di desa Trunyan. Padahal hal ini sangat penting dalam membantu jalannya pelestarian budaya terlebih lagi akan sangat membantu ketika pelaksanaan upacara. Kegiatan ini biasanya digunakan untuk mengajarkan muda mudi tentang budaya yang ada di desanya, meliputi belajar tetabuhan, membuat sarana dan prasarana penting dalam upacara, atau belajar mekidung (pupuh ginada, ginanti, pakangraras dll) yang akan selalu ada di setiap upacara adat khususnya di pura.

Dengan menguatnya identitas kelokalan kita, maka warisan budaya dapat berdialektika dengan identitas kosmopolit yang sifatnya lebih universal di era globalisasi saat ini. Maka kita akan mempunyai fondasi yang kokoh atau posisi tawar untuk bersaing dengan identitas dan ragam kebudayaan yang ditawarkan oleh globalisasi (Al Mudra, 2008). Oleh karena itu, kesadaran masyarakat Bali Aga desa Trunyan akan nilai-nilai kearifan lokal yang terkandung di dalam budayanya, merupakan modal sosial yang kuat dan perlu dipertahankan. Dibutuhkan perhatian khusus dari berbagai pihak terutama pemuda dan lembaga adat desa Trunyan dalam meningkatkan kesadaran masyarakat agar budaya dan kearifan lokal yang menjadi identitas desa Trunyan tetep terpelihara dengan baik dan dapat diwariskan kepada generasi selanjutnya.

\section{SIMPULAN DAN SARAN 3.1. Simpulan}

Berdasarkan sejumlah temuan yang telah dibahas sebelumnya, maka peneliti dapat menyimpulkan beberapa hal sebagai berikut.

1. Kebudayaan yang terdapat dalam masyarakat Bali Aga di desa Trunyan terdiri dari Mepasah, Ngayah, Paruman, dan Barong Brutuk. Sedangkan nilai-nilai kearifan lokal yang terdapat di dalamnya adalah konsep menyama braya. Ini merupakan konsep inti yang berpengaruh besar terhadap keahidupan sosial masyarakat Bali Aga di desa Trunyan yang menganggap semua orang adalah saudara. Dari sanalah dapat dijelaskan prilaku warga negara yang baik.

2. Dalam konteks civic cuture, kehidupan masyarakat ditandai dengan sikap yang menunjukkan nilai-nilai religius, cinta lingkungan, tanggung jawab, saling menghormati, persaudaraan, kepedulian 
HUMANIKA Vol. 23 No.1 (2016) ISSN 1412-9418

Civic Culture Dalam Nilai-Nilai Budaya Dan Kearifan Lokal Masyarakat Bali Aga Desa Trunyan

I Wayan Trisna Mahardika, Cecep Darmawan

sosial, demokrasi, gotong royong, partisipasi, solidaritas, peduli lingkungan.

3. Pelestarian budaya dan kearifan lokal berlangsung secara alamiah mengikuti keterikatan masyarakat yang sangat kuat dengan adat dan kepercayaan. Namun upaya pelestarian belumlah maksimal tanpa adanya kegiatan yang dikhususkan untuk pelestarian budaya dan kearifan lokal di desa Trunyan seperti pasraman atau kegiatan lainnya. Inilah yang menjadi kendala dalam pelestarian budaya dan kearifan lokal di desa Trunyan, generasi muda sebagai penerus hendaknya memiliki peran aktif dalam menjaga dan melestarikan budaya. Sedangkan upaya untuk menanggulangi hal tersebut belum maksimal, sehingga memerlukan tintak lanjut yang lebih jauh.

\subsection{Saran}

Berdasarkan pada kesimpulan di atas, peneliti memberikan beberapa rekomendasi yang ditujukan pada masyarakat, pemerintah, serta penelitian selanjutnya untuk memperhatikan hal-hal sebagi berikut :

1. Masyarakat Bali Aga di desa Trunyan diharapkan dapat memahai nilai-nilai budaya dan kearifan lokalnya sendiri, terlebih lagi mengerti bahwa hal tersebut merupakan bagian dari kekayaan nasional bangsa Indonesia. Menjadikannya dasar dan pegangan dalam kehidupan sehari-hari, oleh karena itu diperlukan sinergi antara pemuda, lembaga desa adat, sesepuh adat, serta seluruh masyarakat Bali Aga di desa Trunyan.

2. Budaya dan kearifan lokal adalah bagian dari budaya kewarganegaraan atau civic culture, oleh karenanya pemahaman dan pengaplikasiannya sangat penting dalam menguatkan karakter kebangsaan. Dengan pemahaman dan keteguhan dalam pengaplikasiannya, maka akan membuat masyarakat menjadi warga negara yang baik dan cerdas (smart and good citizenship).

3. Terakhir adalah diperlukannya sebuah kegiatan yang dikhususkan untuk pelestarian budaya dan kearifan lokal di desa Trunyan. Kegiatan seperti pasraman dapat menjadi tempat dan media bagi generasi muda untuk belajar mengenai budaya mereka sendiri khususnya yang berkaitan dengan upacara-upacara adat. Maka dari itu diperlukan peran aktif dan sinergi dari pemuda, tokoh-tokoh desa, serta pemerintah dalam menyediakan wahana atau media pelestarian budaya masyarakat Bali Aga di desa Trunyan. 


\section{DAFTAR PUSTAKA}

Al Mudra M, (2008). Warisan Budaya dan Makna Pelestariannya. Makalah seminar Budaya dan Busana Melayu Kalimantan Barat, diambil dari www. mahyudinalmudra.com.

Alus, Christeward. (2014). Peran Lembaga Adat dalam Pelestarian Kearifan Lokal Suku Sahu di Desa Balisoan Kecamatan Sahu Kabupaten Halmahera Barat. Jurnal Acta Diurna, III (4), hlm 1-16

Budimansyah, Dasim. (2010). Penguatan Pendidikan Kewarganegaraan untuk Membangun Karakter Bangsa. Bandung: Widya Aksara Press

Creswell, Jhon W. (2010). Reseacrh Design Pendekatan Kualitatif, Kuantitatif dan Mixed. Yogyakarta: pustaka pelajar.

Danandjaja, J. (1989). Kebudayaan Petani Desa Trunyan di Bali. Jakarta:UIPress

Effendi, R. dan Sapriya. (2004). Makna dan Tanggung Jawab Sebagai Warga Negara. Direktorat Jendral Pendidikan Dasar dan Menengah Direktorat Pendidikan Menengah Kejuruan

Koentjaraningrat. (2009). Pengantar Ilmu Atropologi. Jakarta : Rineka Cipta

Muchtar, Suwarma.A. (2015). Dasar Penelitian Kualitatif. Bandung: Gelar Pustaka Mandiri

Nuraeni, H. G. dan Muhammad A. (2013). Studi Budaya di Indonesia. Bandung: CV Pustaka Setia
Sartini. (2004). Menggali Kearifan Lokal Nusantara Sebuah Kajian Filsafati. Jurnal Filsafat, XXXVII (2), hlm. 111-120

Spradley. James. P. (2006). Metode Etnografi. Diterjemahkan dari The Ethnographic Interview. Penerbit: Tiara Wacana: Yogyakarta

Sugiyono. (2009). Metodelogi Penelitian Kuantitatif Kualitatif Dan $R \& D$. Bandung : Alfabeta

Undang-Undang Dasar Negara Republik Indonesia Tahun 1945 pada pasal 32 ayat 1 dan 2

Winataputra, U. S. (2012). Pendidikan Kewarganegaraan dalam Perspektif Pendidikan untuk Mencerdaskan Kehidupan Bangsa (Gagasan, Instrumentasi, dan Praksis). Bandung: Widya Aksara Press

Winataputra, U. S. (2012). Pendidikan Kewarganegaraan dalam Perspektif Internasional (Konteks, Teori, dan Profil Pembelajaran). Bandung : Widya Aksara Press

Winataputra, U. S. dan Budimansyah. D. (2007). Civic Education: Konteks, Landasan, Bahan Ajar dan Kultur Kelas. Bandung: Program Studi Pendidikan Kewarganegaraan Sekolah Pascasarjana Universitas Pendidikan Indonesia

Catatan : Naskah ini layak untuk diterbitkan, dengan beberapa perbaikan redaksional. 